Int. J. Electrochem. Sci., 16 (2021) Article ID: 210815

International Journal of

ELECTROCHEMICAL

SCIENCE

$\underline{\text { www.electrochemsci.org }}$

\title{
Novel Calcium Potentiometric Selective Electrode Based on Lisinopril Functionalized Multi-walled Carbon Nanotubes-NiO Nanocomposite
}

\author{
Nehad A. Abdallah ${ }^{1,2}$ \\ ${ }^{1}$ Pharmacognosy and Pharmaceutical Chemistry Department, College of Pharmacy, Taibah University, \\ Al-Madinah Al-Mounawarah 30078, KSA \\ ${ }^{2}$ Experiments and Advanced Pharmaceutical Research Unit, Faculty of Pharmacy, Ain Shams \\ University, Cairo 1156, Egypt. \\ *E-mail: nehad.amin@gmail.com
}

doi: $10.20964 / 2021.08 .21$

Received: 25 March 2021 / Accepted: 12 May 2021 / Published: 30 June 2021

A novel carbon paste electrode utilizing a lisinopril molecule as a recognition element for the selective determination of free $\mathrm{Ca}^{2+}$ ions was developed. The fabrication of the sensor was established by the covalent attachment of lisinopril to the surface of the MWCNTs-NiO nanocomposite. The formed composite was characterized by FT-IR, TEM, and XRD. This unique design has led to high selectivity and stability of the studied carbon paste electrode. It revealed a Nernstian slope of $30.4 \pm 0.52 \mathrm{mV} / \mathrm{decade}$ with wide linearity ranging from $1 \times 10^{-2} \mathrm{~mol} \mathrm{~L}^{-1}$ to $1 \times 10^{-8} \mathrm{~mol} \mathrm{~L}^{-1}$. The electrode showed high sensitivity to $\mathrm{Ca}^{2+}$ ion. The LOD was found to be $3.5 \times 10^{-9} \mathrm{~mol} \mathrm{~L}^{-1}$. The proposed sensor was successfully applied for the determination of $\mathrm{Ca}^{2+}$ concentration in various media such as pharmaceutical tablets, tap water, soil drainage water samples and human serum samples. The resulted recovery of the sensor was in the range of $94.2 \%-102.1 \%$ with acceptable precision and reproducibility.

Keywords: Calcium; Carbon paste electrode; potentiometry; MWCNTs; NiO nanoparticles; Lisinopril

\section{$\underline{\text { FULL TEXT }}$}

(C) 2021 The Authors. Published by ESG (www.electrochemsci.org). This article is an open access article distributed under the terms and conditions of the Creative Commons Attribution license (http://creativecommons.org/licenses/by/4.0/). 